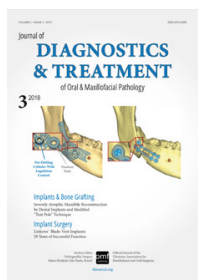

OBITUARY

\title{
Obituary for Dr. José Guerrerosantos: A Teacher Who Continues to Live in the Works of His Disciples
}

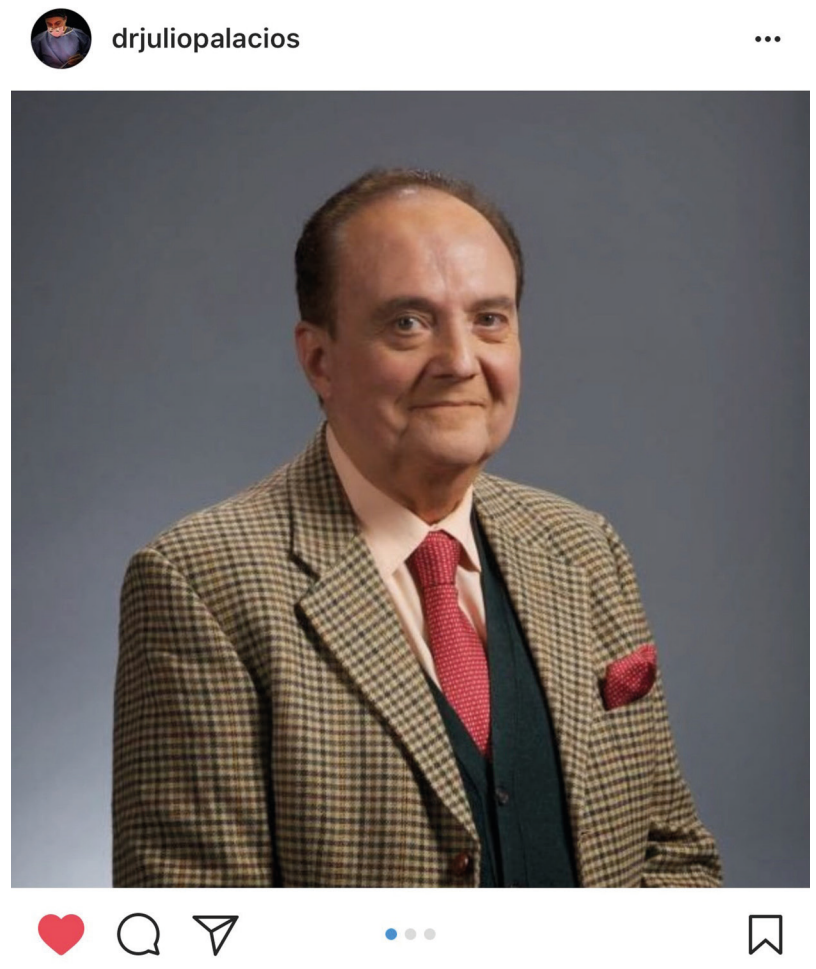

Liked by plasticsurgery, dr.robertgaliano and 55 others

drjuliopalacios "El que prudente medita,muchos pesares evita"... José Guerrerosantos (1932-2017) - Nació en Jalisco, México el 26 de Febrero, egresó de la Escuela de Medicina de la Universidad de Guadalajara y continuó su formación en la Universidad de Illinois, en Chicago. - En 1976 fundó el Instituto Jaliscience de Cirugía Reconstructiva.

- Publicó múltiples artículos científicos entre los que destacan el del colgajo de lengua y el tratamiento de platisma, entre otros.

- "El Maestro" es gratamente recordado por sus alumnos como un ser humano excepcional, que siempre mantuvo el afán de compartir lo que sabía.

\#cirugiaplastica \#plasticsurgery \#plasticsurgeon

\#cirujanoplastico \#maestro \#jalisco \#mexico I.

\#iwanabelikevou \#ciruaiareconstructiva
Legend of plastic surgery, the great founder has gone. José Guerrerosantos, M.D. (Fig 1), was not only a Director and Plastic Surgeon in Charge, The Jalisco Plastic and Reconstructive Surgery Institute; Professor and Chairman of the Division of Plastic and Reconstructive Surgery, University of Guadalajara Medical College, Guadalajara, Mexico. He was a founding father of the Instituto Jalisciense de Cirugia Reconstructiva (The Jalisco Plastic and Reconstructive Surgery Institute), a hospital affiliated with the University of Guadalajara, Jalisco, Mexico [1]. One of his scientific "children" - Manual of Aesthetic Surgery (editors: Fisher JC, Guerrerosantos J, Gleason M) (Fig 2) is a state of art textbook [2], an immortal masterpiece, which continues to navigate next generations of plastic surgeons in the extremely responsible field of surgery. The sacred Manual, which is a testament for surgeons of different subspecialties. Also, contribution of Professor José Guerrerosantos to the flap of tongue is really helped to lift a flap surgery to the new heights. Professor Guerrerosantos was born as a son of Mexico and will continue to live in his creations, our minds, and the works of his disciples. And it's very symbolic, that his students and disciples named and still names him the same name as a Jesus was called... "a Teacher"..

FIGURE 1. Translation of the Instagram post of Dr. Julio Palacios (Mexico City, Mexico): "'The one who prudent meditates, many sorrows avoids" ... José Guerrerosantos (1932-2017) - he was born in state Jalisco (Mexico) on February 26. Graduated from the School of Medicine of the University of Guadalajara (Mexico) and continued his training at the University of Illinois (Chicago, IL, USA). In 1976 he founded the Jalisco Plastic and Reconstructive Surgery Institute [1] (Guadalajara, state Jalisco, Mexico.)

- Published multiple scientific articles among which stand out the tongue flap and the platysma treatment, among others.

- "El Maestro" is pleasantly remembered by his students as an exceptional human being, who always maintained the desire to share what he knew." 
Comprehensive Manuals of Surgical Specialties

\section{Manual of Aesthetic Surgery}
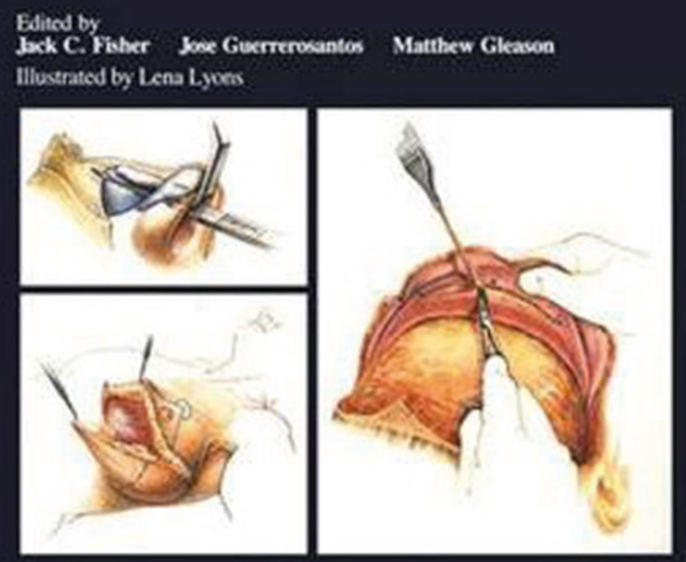

Springer Vertag New Yook Berlin Heidelbers Tokyo

FIGURE 2. Front cover of the Manual of Aesthetic Surgery (editors: Fisher JC, Guerrerosantos J, Gleason M. New York: Springer-Verlag).

\section{References}

1. Cueva-Galárraga M, Cárdenas-Camarena L, Boquín M, Robles-Cervantes JA, Guerrerosantos J. Aesthetic plastic surgery training at the Jalisco plastic and reconstructive surgery institute: a 20-year review. Plast Reconstr
Surg 2011;127(3):1346-51. http://dx.doi.org/10.1097/ PRS.0b013e318205f317.

2. Fisher JC, Guerrerosantos J, Gleason M. Manual of aesthetic surgery. 1st ed. New York: Springer-Verlag; 1985. http:// dx.doi.org/10.1007/978-1-4612-5052-4.

Julio Palacios Juárez, MD

Mexico City, Mexico drpalacios.cirplast@icloud.com

Instagram: drjuliopalacios

Ievgen I. Fesenko, DDS, PhD Managing Editor Kyiv, Ukraine i.i.fesenko@dtjournal.org Instagram: dr_eugenfesenko 